\title{
Symptoms of Ekbom Syndrome and Its Treatment with Trifluoperazine
}

\section{Ekbom Sendromu Belirtileri ve Trifluoperazin Kullanımı ile Tedavisi}

\author{
Mehmet Hamdi Örüm \\ Kahta State Hospital, Clinic of Psychiatry, Adıyaman, Turkey \\ Copyright (c) 2020 by authors and Medical Records Publishing Inc.
}

\begin{abstract}
Substance use may result in schizophrenia. Ekbom syndrome is characterized by the conviction of being infested by invisible mites or insects, despite clear evidence of the contrary and can be seen in schizophrenia. These patients usually go to non-psychiatric physicians and have lost faith in psychiatric treatment during psychiatric admission. Therefore, early diagnosis and subsequent psychiatric treatment are important. Antipsychotics can be used for treatment, but drug response characteristics vary. Conventional antipsychotics can be considered when there is no response with the commonly used drugs. In this case report, we present a male patient with Ekbom syndrome who had symptomatic improvement with short-term trifluoperazine therapy..
\end{abstract}

Keywords: Ekbom syndrome, delusional infestation, trifluoperazine, pseudo-hallucination

$\mathrm{Oz}$

Madde kullanımı şizofreni ile sonuçlanabilir. Ekbom sendromu, herhangi bir kanıt olmadan parazitlerle enfekte olduğu sabit ve yanlış öznel inancı ile karakterizedir ve şizofrenide görülebilir. Bu hastalar genellikle psikiyatri dışı hekimlere başvururlar ve psikiyatrik başvuru sırasında psikiyatrik tedaviye olan inançlarını kaybetmişlerdir. Bu nedenle erken tanı ve takip eden psikiyatrik tedavi önemlidir. Antipsikotikler tedavide kullanılabilir, ancak ilaç yanıt özellikleri değişkenlik gösterir. Yaygın olarak kullanılan ilaçlarla herhangi bir yanıt alınmadığında, geleneksel antipsikotikler düşünülebilir. Bu olgu sunumunda, kısa süreli trifluoperazin tedavisi ile semptomatik iyileşme gösteren Ekbom sendromlu bir erkek hastayı sunuyoruz..

Anahtar Kelimeler. Ekbom sendromu, delüzyonel infestasyon, trifluoperazin, yalancı halüsinasyon

\section{INTRODUCTION}

Cannabis is a widely used illegal substance and its use is increasing in the general population (1). Various psychiatric disorders related to cannabis use may occur. Psychosis is a condition which is the most severe clinical outcome of these disorders (2). Psychotic attacks can be triggered directly by cannabis use and/or cannabis use may cause an early occurrence of a possible psychotic attack $(3,4)$. Sudden onset of mood lability and paranoid symptoms are clear features of cannabis-induced psychosis. Chronic cannabis use can cause irreversible psychosis, schizophrenia and present with delusions (4). Delusional parasitosis, also known as Ekbom syndrome, is a rare psychiatric disorder which is characterized by feelings of parasites or insects under the skin. Although the diagnostic criteria of Ekbom syndrome have been defined, there is no consensus on its treatment. Typical antipsychotics can be used in the treatment of Ekbom syndrome (5). Trifluoperazine is a phenothiazine derivative and a dopamine antagonist with antipsychotic activity (6). In this case report, we discussed the complete remission with trifluoperazine in a patient whose Ekbom syndrome symptoms persisted despite the use of multiple psychotropic drugs.

\section{CASE PRESENTATION}

Mr. A., 33-year-old, married, male patient was admitted to the psychiatric outpatient clinic with complaint of scalp insect infestation lasting for 10 days. He was using carbamazepine $800 \mathrm{mg} /$ day per oral (PO), mirtazapine 30 $\mathrm{mg} /$ day PO, sertraline $100 \mathrm{mg} /$ day PO, quetiapine $800 \mathrm{mg} /$ 
day PO and olanzapine $20 \mathrm{mg} /$ day PO with the diagnosis of schizophrenia. General and systemic examination was within normal limits. Mental status examination revealed aggression and insomnia symptoms, depressive mood, pseudo-hallucination and somatic delusion. Toxic screening in urine gave negative results. The patient's thyroid and liver function tests were within normal limits. The fasting blood glucose, protein level and lipid profile were within normal limits. Chest X-ray, electroencephalogram and magnetic resonance imaging gave normal results. The patient and relatives stated that there was no change in dietary and fluid intake in recent days and the patient was using his drugs favourably. The patient had a history of cannabis use and had not used any substance for 2 years. He had a history of inpatient treatment for a psychotic episode one year ago. Family history was unremarkable. His toxic screening in urine a month ago and two weeks ago were also negative. The story taken from him and his family did not suggest an intoxication or withdrawal.

The patient thought that insects had come out of his hair and had entered his mouth. The patient was consulted to the dermatologist with these complaints. The dermatologist did not report any organic pathology. However, this information did not satisfy the patient, insisted on his complaint. Thereupon, Ekbom syndrome was considered and trifluoperazine $2 \mathrm{mg} /$ day PO (tablet form) was started and the dose was increased to $6 \mathrm{mg} / \mathrm{day}$ PO day by day. The sertraline dose was increased to 100 $\mathrm{mg} /$ day $\mathrm{PO}$ because his depressive symptoms persisted despite sertraline $50 \mathrm{mg} /$ day PO; other medications were continued at the same dose. The compliance of the patient to the treatment was determined by obtaining information from the family. One week after the addition of trifluoperazine, the patient's symptom of Ekbom syndrome improved significantly. Possible side effects were questioned. The patients and their relatives were informed about the effects and possible side effects of the medications. No similar side effects were reported during the follow-up of the patient. The informed written consent has obtained from the patient for publication.

\section{DISCUSSION}

Cannabis use may result in psychosis and delusions such as Ekbom syndrome (7). The symptom of Ekbom syndrome continues even though there is no medical evidence of parasites or small insects that the patient claims invaded his body. Because these patients have symptoms related to the skin, they mostly refer to nonpsychiatric physicians and are not compatible with psychiatric treatment. Patients often experience an itch that binds to the presence of parasites under or in their skin. They try to save their skin by scraping from these parasites, disinfectants and pesticides. This causes skin lesions and reinforces the patient's false belief. This causes a vicious cycle of skin lesions, itching and delusional belief (8).

In most cases of delusional parasitosis, once symptoms have settled, response to treatment is generally low. The mean disease duration was reported to be three years. The delusional system settles and becomes chronic in patients who remain untreated for long periods of time (9). Ekbom syndrome may be primary or secondary (5). Patients' medications and substance use status should be questioned. In our patient, possible causes were excluded; illicit drug use, organic diseases; dermatologic conditions. In our patient, symptoms were treated before a possible vicious cycle and treatment was improved. There is no consensus on the most appropriate treatment (8). Typical antipsychotics, atypical antipsychotics, antidepressants, electroconvulsive therapy and dermatological agents can be used individually or in combination. Traditionally, typical antipsychotic pimozide has been considered as first choice, but pimozide has various serious side effects $(10,11)$. While antipsychotic drugs provide significant treatment in primary delusional parasitosis, they are used only symptomatically in cases secondary to somatic diseases and the treatment of the underlying disease is required (9). In studies, partial or complete remission rates with typical antipsychotics have been reported as $60-100 \%$. Our patient was taking many drugs from different groups at high doses. Consistent with the literature, complete remission was achieved in a short time with trifluoperazine.

This study is valuable in some aspects. First, patients' delusions and hallucinations should be questioned at every admission. This will provide an early diagnosis of any new condition or change. Early treatment of existing symptoms will prevent the patient from chronicity. In this case report, Ekbom syndrome symptoms were treated before the vicious circle appeared. On the other hand, in patients who already use many psychotropic drugs, less preferred drugs should be rethought. Trifluoperazine is a drug that can be used for this purpose.

In conclusion, this case report is important in terms of showing that trifluoperazine use is a treatment option in patients with Ekbom syndrome. It is recommended that clinicians keep in mind the use of trifluoperazine in this disorder. Further systematic research should be conducted with respect to trifluoperazine use in Ekbom syndrome to provide a greater understanding of both its prevalence and etiology.

Financial disclosures: All authors report no financial interests or potential conflicts of interest.

Conflict of Interest: The authors declare that they have no competing interest.

\section{ORCID ID}

Mehmet Hamdi Örüm,

http://orcid.org/0000-0002-4154-0738

\section{REFERENCES}

1. Orum MH, Kustepe A, Kara MZ, Dumlupinar E, Egilmez OB, Ozen ME, Kalenderoglu A. Addiction profiles of patients 
with substance dependency living in Adiyaman province. Medicine Science 2018;7(2):369-72.

2. Orum $M H$, Kara MZ, Egilmez OB, Ozen ME, Kalenderoglu A. Evaluation of probation implementations of drug users in Adiyaman university training and research hospital: A oneyear retrospective study. Medicine Science 2018;7(4):754-8.

3. Beckmann D, Lowman KL, Nargiso J, McKowen J, Watt L, Yule AM. Substance-induced psychosis in youth. Child Adolesc Psychiatr Clin N Am 2020;29(1):131-43.

4. Özen ME, Örüm MH, Kalenderoğlu A. Hot shower therapy in cannabinoid hyperemesis syndrome: A case report. FNG \& Bilim Tıp Dergisi 2018;4(3):142-4.

5. Mumcuoglu KY, Leibovici V, Reuveni I, Bonne O. Delusional parasitosis: Diagnosis and treatment. Isr Med Assoc J 2018;20(7):456-60.

6. Howland $\mathrm{RH}$. Trifluoperazine: A sprightly old drug. J Psychosoc Nurs Ment Health Serv 2016;54(1):20-2.
7. Farris MS, Shakeel MK, Addington J. Cannabis use in individuals at clinical high-risk for psychosis: a comprehensive review. Soc Psychiatry Psychiatr Epidemiol 2019. Doi: 10.1007/s00127-019-01810-x.

8. Campbell EH, Elston DM, Hawthorne JD, Beckert DR. Diagnosis and management of delusional parasitosis. J Am Acad Dermatol 2019;80(5):1428-34.

9. Karakus G. Delusional parasitosis: Clinical features, diagnosis and treatment. Current Approaches In Psychiatry 2010;2(3):384-400.

10. Barone $Y$, Niolu C, Zanasi M, Siracusano A. Ekbom syndrome treated with olanzapine: a case report Sindrome di Ekbom trattata con olanzapina: un caso clinic. Journal of Psychopathology 2014;20:66-8.

11. Orum $\mathrm{MH}$, Egilmez $\mathrm{OB}$. Compulsive water drinking resulting in hyponatremia: A pimozide case. Med Records 2019;1(2):48-9. 